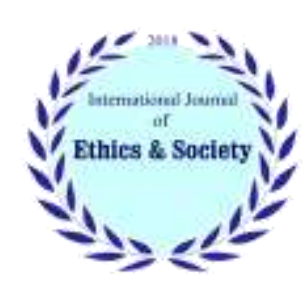

International Journal of Ethics \& Society (IJES)

Journal homepage: $\underline{\text { www.ijethics.com }}$

Vol. 2, No. 4 (2021)

(Original article)

\title{
Bank Ethical Responsibility to Compensate for Services Failure \& Its Revival
}

\section{Mina Khalili Kisami ${ }^{a}$, Karim Hamdi ${ }^{*}$, Hossein Vazifehdoust ${ }^{\mathrm{a}}$, Farhad Hosseinzadeh Lotfi ${ }^{b}$}

\author{
a) Dept, of Business Management, Faculty of Management \& Economy, Islamic Azad University, Science \& Research \\ Branch, Tehran, Iran \\ b) Dept. of Mathematics, Faculty of Basic Sciences, Science \& Research Branch, Islamic Azad University, Tebran, Iran
}

\section{Abstract}

Background: Unlike banking development in country, banks have not been able to satisfy customers yet. Therefore, the present study aimed at investigating banks ethical responsibility to compensate for services failure and reviving it.

Method: This study is applied in purpose, exploratory in approach and mixed (qualitative-quantitative) in data analysis. In qualitative phase and in order to design a model based on grounded theory, a group of experts in banking management and services marketing (including university professors, bank CEOs and banking industry marketing counselors) selected as society and 11 have been selected through snowball sampling and until reaching theoretical saturation. In-depth-interview was research instrument in this phase and data analyzed through coding. In quantitative phase, banking industry customers in Tehran considered as statistical society and 400 of them selected through cluster sampling with equal volume as statistical sample. In quantitative phase also the research instrument was researcher-made and closed questionnaire and path analysis and SPSS and Lisrel used to analyze data.

Results: 134 primary concepts extracted in this study that 51 ultimate concepts classified in 31 main categories. This results lead to designing failure procedural pattern and reviving services in Iran's banking industry (based on paradigmatic model structure) and model hypothetical relationships tested and approved in a wide society. Conclusion: Customer satisfaction and loyalty depends on organization adherence to professional ethics and responsibility that the most important sign of an organization responsibility is organized activity to compensate for services failure and reviving it.

Keywords: Ethical responsibility, Services failure, Customer satisfaction

* Corresponding Author: Email: Hamdi_Karim1@yahoo.com

Received: 14 Jan 2021

Accepted: 17 Feb 2021

18

Available at: www.ijethics.com 


\section{Introduction}

Considering professional ethics, all agencies and organizations have to offer appropriate services with high quality to customers and all agencies have to be accountable to their services failure and be responsible (1). Failure and services weak reviving is among the major factors which turns away customers (2). Service providers are mostly encouraged to offer services with minimum errors and reviving deficient services effectively is necessary to fulfill customers' satisfaction and removing negative word-of-mouth advertising (3).

Studies in Iran banking system show that despite banking development and providing new methods to use banking services; measures have not satisfied customers yet and they are still unsatisfied with banks' attitude and facilitation. Recently, bank electronic services are expanding rapidly, but despite electronic banking development, many people refer to banks to receive services and facilities. One of the biggest problems people face with them when referring to the banks is related to receiving bank facilities, this problem not only includes normal people but also includes private section producers and actives and they complain about various problems in receiving facilities from banks. These are not only related to private and or governmental banks and include all banks. Another point which people complain about it when referring to banks branches is how banks staff behave with them which is sometimes disrespectful and immoral and almost all bank referents put emphasis on it.

These days, banking network is highly criticized and although bankers try to blame wrong monetary and financial policies for their shortcomings and regard governmental duties as the main fault, people do not pay attention to it and demand to improve services receiving condition and respecting clients perfectly in banks branches especially in privatized banks (4). Not fulfilling expectations from services as a result of service failure leads to customer dissatisfaction (5) and saying negative words (6). Continuing providing weak services threatens company survival in long term. In other words, if service companies do not manage services reviving cor- rectly, this may damage their long term achievement landscapes. When companies provide appropriate services considering professional ethics principles and deal with complaints effectively, it may influence customer retention rate significantly and it will prevent destructive word-of-mouth words and improves ultimate performance. When customers' complaints are dealt well and relationship between company and customer improves and agency be responsible to customers, this may improve satisfaction, trust and customer commitment to that company (7). So reviving service is a vital and efficient business strategy to return unsatisfied customers and keeping in touch with them as this shows agency responsibility and its commitment to professional ethics. Reviving efficient services to service providers makes it possible to satisfy customers again, maintain their loyalty and make a long term relationship with them. Therefore, the importance and effects of reviving services for marketers and researchers is vital to recognize it better (8).

According to what has been mentioned and considering that banking industry of country suffers from a comprehensive and native model in failure and reviving services field and considering that actives in this industry are not provided with a comprehensive and guiding model to align strategic and tactical measures in failure and reviving services field, the researchers aimed at describing a comprehensive procedural pattern putting emphasis on banks moral responsibility to compensate for services failure and reviving it.

\section{Material and Methods}

The present study is applied in purpose and applied-exploratory in approach which is conducted in mixed method.

\section{Qualitative Phase}

Qualitative phase of study conducted based on grounded theory. A group of experts in banking management and services marketing including uni- 
versity professors, bank CEOs and banking industry marketing counselors selected as society, expertise characteristics include the following items: mastering services marketing management issues, service failure in banking system, reviving services in banking system, satisfaction and loyalty of banking industry customers, customers behavior and their preferences in banking industry. 11 of them have been selected through snowball sampling and until reaching theoretical saturation as sample. Research instrument was deep interview in this study. The researcher tried to ask questions about precedents, failure fields and reviving services in banking industry, effective environmental factors on it, consequences of this event and... through entering the discussion softly and gaining interviewees' early trust perfectly indirectly and obtained primary concepts to design model. Finally, data analyzed by Tri- ple Data Encryption Algorithm (TDEA) (open, axial and selective) to obtain research conceptual model.

\section{Quantitative Phase}

Descriptive-correlative method used in this part. Research society was banking industry customers in Tehran that 400 of them selected through cluster sampling with equal volume as statistical sample (at least 384 statistical samples needed based on Krejcie and Morgan Table for a society with this volume). Data collecting instrument was closed and researcher-made questionnaire including 42 items which was designed based on initial conceptual model. It worth mentioning that questions deigned based on five-degree Likert scale in this questionnaire and a range of "agreement" was used. The following table shows the structure of this questionnaire based on its different dimensions:

Table 1. The questionnaire structure of research quantitative phase

\begin{tabular}{|c|c|c|}
\hline Variable & $\begin{array}{l}\text { Naming in } \\
\text { software }\end{array}$ & $\begin{array}{l}\text { Related items } \\
\text { in questionnaire }\end{array}$ \\
\hline Bank staff behavior & Var1 & 1 to 3 \\
\hline Bank services comprehensiveness & Var2 & 4 to 6 \\
\hline Bank services appropriateness with customers' needs & Var3 & 7 to 9 \\
\hline The quality of services provided by bank & Var4 & 10 to 14 \\
\hline Bank physical quality & Var5 & 15 to 18 \\
\hline Customer's attitude & Var6 & 19 to 21 \\
\hline Customer's expectations & Var7 & 22 to 24 \\
\hline Customer's perception facing with service & Var8 & 25 to 27 \\
\hline The behavior of other present customers in bank branch & Var9 & 28 to 30 \\
\hline The opinions of friends and family about bank & Var10 & 31 to 33 \\
\hline The system of receiving and dealing with bank customers' complaints & Var11 & 34 to 36 \\
\hline The system of managing communications with bank customers & Var12 & 37 to 39 \\
\hline Bank customers' satisfaction and loyalty & Var13 & 40 to 42 \\
\hline
\end{tabular}

In order to analyze data and test research hypotheses, SPSS and Lisrel statistical soft-wares and descriptive statistics (mean, SD, frequency and...) and inferential tests (Cronbach's alpha, structure validity, confirmatory factor analysis and path analysis) were used.

\section{Results}

Quantitative Phase (designing primary model based on grounded theory approach)
Totally 11 interviews have been done in this study, 134 primary concepts extracted that 51 ultimate concepts identified after investigating and juxtaposing with each other and removing repetitive concepts. Then more general classifications called "categories" made considering identified concepts deeply and recognizing their similarities and differences and equal and similar concepts placed in these more general groups. The result of this process was identifying 13 major categories. Then, 31 identified categories placed in paradigmatic model structure: 
Major Category (Axial): it is an idea, event or accident that concepts and categories are created based on it. Considering the identified purposes and categories, the category of "customer's perception facing with service" considered as major and axial category in this study. That is the core of conceptual model is the positive and negative perception (failure) of customer of services quality received from bank branch.

Causative Conditions: a set of conditions which creates, strengthens or weaken a phenomenon. Categories related to this dimensions are determined as follows:

- Bank staff behavior: this category refers to how bank staff behave and talk to customers.

- Bank services comprehensiveness: this category refers to bank services diversity and range.

- Bank services appropriateness with customers' needs: this category refers to the appropriateness and alignment of service basket provided by bank with customers' present and future needs.

- The quality of services provided by bank: this category refers to how bank provides services and speed, accuracy and order in providing services.

- Bank physical quality: this category refers to branches building quality, easy access to branches for customers, parking lot around branches, facilities in branches for customers waiting to receive services and...

Fields: it shows special conditions where phenomenon (major category) exists and happens. Considering identified purposes and identified categories, the categories of "customer's attitude" and "customer's expectations" considered as field categories in this study. Customer's attitude refers to the type of customer's view to the bank from which receives services and customer's expectations also refers to customer's obvious and hidden expectations before receiving banks services.

Environmental Conditions: they are wide structural field and external factors which may influence major category and even strategies. Considering identified purposes and categories, the categories of "the behavior of other present customers in bank branch" and "the opinions of friends and family about bank" considered as environmental categories in this study. That is the type of other customers' behavior in bank branch (considering that they complain about bank services or not and or they comment on bank) and also comments of friends and family about bank may influence customers' perceptions of received services.

Strategies: a specific set of strategies and measures is feasible in a field and with specific mediating condition. In fact, strategies are measures which may change major categories to consequences. Considering identified purposes and categories, the categories of "the system of receiving and dealing with bank customers" complaints" and "the system of managing communications with bank customers" considered as strategic categories in this study. The system of receiving and dealing with bank customers refers to the mechanisms that bank has designed and performed to receive and deal with its customers' complaints; moreover, the system of managing communications with bank customers also refers to electronic or non-electronic communications of bank with customers (before, during and after providing services).

Consequences: it refers to the consequences of axial category achievement in causative, environmental and field conditions and through specific strategies. Considering identified purposes and categories, the category of 'bank customers' satisfaction and loyalty" considered as consequential category in this study. That is if causative conditions, fields, major category, environmental conditions and strategic conditions happen well and probable failures in services managed using suitable strategies, it is hoped that satisfaction and loyalty happen in customers.

The next step is placing categories in paradigmatic model which leads to identifying research conceptual model. Figure (1) shows the main formation of this model: 


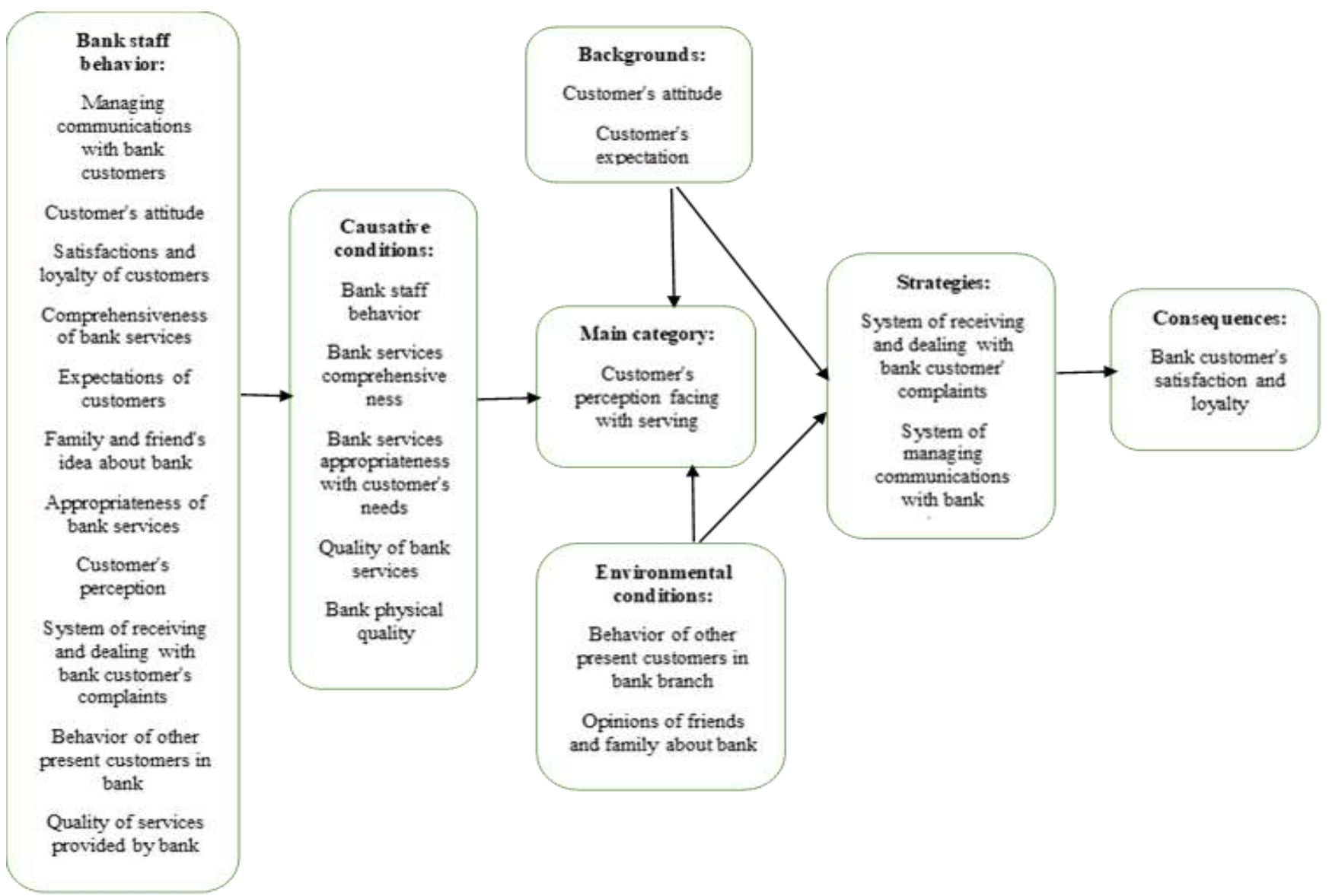

Figure 1: Research conceptual model

According to the above model, research hypotheses are prepared as follows:

- There is significant relationship between bank staff behavior and customer's perception facing with service.

- There is significant relationship between bank services comprehensiveness and customer's perception facing with service.

- There is significant relationship between bank services appropriateness and customer's perception facing with service.

- There is significant relationship between the quality of services provided by bank and customer's perception facing with service.

- There is significant relationship between bank physical quality and customer's perception facing with service.
- There is significant relationship between customer's attitude and customer's perception facing with service.

- There is significant relationship between customer's expectations and customer's perception facing with service.

- There is significant relationship between other present customers in bank branch and customer's perception facing with service.

- There is significant relationship between the opinions of friends and family about bank and customer's perception facing with service.

- There is significant relationship between customer's attitude and the system of receiving and dealing with bank customer's complaints.

- There is significant relationship between customer's attitude and the system of managing communications with bank customers. 
- There is significant relationship between customer's expectations and the system of receiving and dealing with bank customer's complaints.

- There is significant relationship between customer's expectations the system of managing communications with bank customers.

- There is significant relationship between other present customers in bank branch and the system of receiving and dealing with bank customer's complaints.

- There is significant relationship between other present customers in bank branch and the system of managing communications with bank customers.

- There is significant relationship between the opinions of friends and family about bank and the system of receiving and dealing with bank customer's complaints.

- There is significant relationship between the opinions of friends and family about bank and the system of managing communications with bank customers.
- There is significant relationship between the system of managing communications with bank customers and bank customers' satisfaction and loyalty.

- There is significant relationship between the system of receiving and dealing with bank customer's complaints and customers' satisfaction and loyalty.

Quantitative Phase (explaining research model by Structural Equations Modeling (SEM) approach):

Several criteria are used to investigate structural models fitting that the first criterion to measure structures relations in model is t-values and numbers have to be either more than 1.96 or less than 1.96 to approve the correctness of relationship between structures and research hypotheses at 95\% confidence interval. But it is worth mentioning that $\mathrm{t}$-values only show the correctness of relationships and it may not measure the severity of relationships between structures.

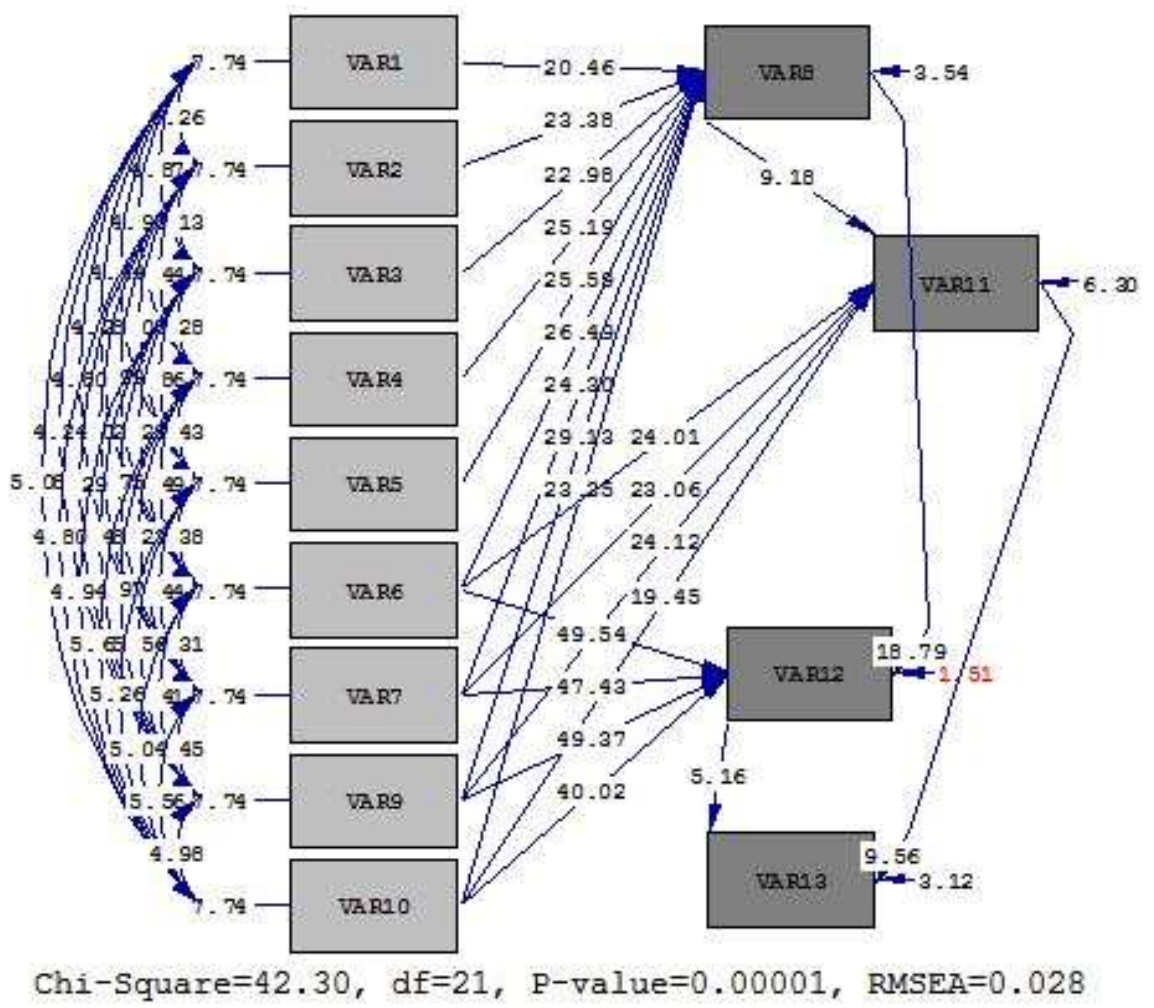

Figure 2: Research fitted model in t-value 
Hamdi K. et al.

International Journal of Ethics \& Society (IJES), (2021) Vol. 2, No. 4

Model paths t-values coefficients show that whether research hypotheses are significant or not? If t-value coefficient of path between two variables be more than 1.96 or less than -1.96 , it is demonstrative of those two variables significant effect at 95\% confidence interval and research hypothesis is approved. The following table summarizes t-value coefficients and hypotheses results:

Table 2. The results of research hypotheses test

\begin{tabular}{|c|c|c|}
\hline Hypotheses & t-value & Result \\
\hline $\begin{array}{l}\text { There is significant relationship be- } \\
\text { tween bank staff behavior and cus- } \\
\text { tomer's perception facing with ser- } \\
\text { vice. }\end{array}$ & $46 / 20$ & Approved \\
\hline $\begin{array}{l}\text { There is significant relationship be- } \\
\text { tween bank services comprehensive- } \\
\text { ness and customer's perception facing } \\
\text { with service. }\end{array}$ & $38 / 23$ & Approved \\
\hline $\begin{array}{l}\text { There is significant relationship be- } \\
\text { tween bank services appropriateness } \\
\text { and customer's perception facing } \\
\text { with service. }\end{array}$ & $98 / 22$ & Approved \\
\hline $\begin{array}{l}\text { There is significant relationship be- } \\
\text { tween the quality of services provided } \\
\text { by bank and customer's perception } \\
\text { facing with service. }\end{array}$ & $19 / 25$ & Approved \\
\hline $\begin{array}{l}\text { There is significant relationship be- } \\
\text { tween bank physical quality and cus- } \\
\text { tomer's perception facing with ser- } \\
\text { vice. }\end{array}$ & $58 / 25$ & Approved \\
\hline $\begin{array}{l}\text { There is significant relationship be- } \\
\text { tween customer's attitude and cus- } \\
\text { tomer's perception facing with ser- } \\
\text { vice. }\end{array}$ & $49 / 26$ & Approved \\
\hline $\begin{array}{l}\text { There is significant relationship be- } \\
\text { tween customer's expectations and } \\
\text { customer's perception facing with } \\
\text { service. }\end{array}$ & $30 / 24$ & Approved \\
\hline $\begin{array}{l}\text { There is significant relationship be- } \\
\text { tween other present customers in } \\
\text { bank branch and customer's percep- } \\
\text { tion facing with service. }\end{array}$ & $13 / 29$ & Approved \\
\hline $\begin{array}{l}\text { There is significant relationship be- } \\
\text { tween the opinions of friends and } \\
\text { family about bank and customer's } \\
\text { perception facing with service. }\end{array}$ & $25 / 23$ & Approved \\
\hline $\begin{array}{l}\text { There is significant relationship be- } \\
\text { tween customer's attitude and the sys- } \\
\text { tem of receiving and dealing with } \\
\text { bank customer's complaints. }\end{array}$ & $01 / 24$ & Approved \\
\hline $\begin{array}{l}\text { There is significant relationship be- } \\
\text { tween customer's attitude and the sys- } \\
\text { tem of managing communications } \\
\text { with bank customers. }\end{array}$ & $54 / 49$ & Approved \\
\hline $\begin{array}{l}\text { There is significant relationship be- } \\
\text { tween customer's expectations and }\end{array}$ & $06 / 23$ & Approved \\
\hline
\end{tabular}

\begin{tabular}{|l|l|l|}
\hline $\begin{array}{l}\text { the system of receiving and dealing } \\
\text { with bank customer's complaints. }\end{array}$ & & \\
\hline $\begin{array}{l}\text { There is significant relationship be- } \\
\text { tween customer's expectations the } \\
\text { system of managing communications } \\
\text { with bank customers. }\end{array}$ & $43 / 47$ & Approved \\
\hline $\begin{array}{l}\text { There is significant relationship be- } \\
\text { tween other present customers in } \\
\text { bank branch and the system of receiv- } \\
\text { ing and dealing with bank customer's } \\
\text { complaints. }\end{array}$ & & \\
\hline $\begin{array}{l}\text { There is significant relationship be- } \\
\text { tween other present customers in } \\
\text { bank branch and the system of man- } \\
\text { aging communications with bank cus- } \\
\text { tomers. }\end{array}$ & & \\
\hline $\begin{array}{l}\text { There is significant relationship be- } \\
\text { tween the opinions of friends and } \\
\text { family about bank and the system of } \\
\text { receiving and dealing with bank cus- } \\
\text { tomer's complaints. }\end{array}$ & $45 / 19$ & Approved \\
\hline $\begin{array}{l}\text { There is significant relationship be- } \\
\text { tween the opinions of friends and } \\
\text { family about bank and the system of } \\
\text { managing communications with bank } \\
\text { customers. }\end{array}$ & & \\
\hline $\begin{array}{l}\text { There is significant relationship be- } \\
\text { tween the system of managing com- } \\
\text { munications with bank customers and } \\
\text { bank customers' satisfaction and loy- } \\
\text { alty. }\end{array}$ & $56 / 9$ & \\
\hline $\begin{array}{l}\text { There is significant relationship be- } \\
\text { tween the system of receiving and } \\
\text { dealing with bank customer's com- } \\
\text { plaints and customers' satisfaction } \\
\text { and loyalty. }\end{array}$ & & \\
\hline & & \\
Approved \\
\end{tabular}

\section{Discussion}

According to the results of the present study, the major category (axial) that banks have to consider to compensate for services failure was the category of "customer's perception facing service" which was influenced by causative conditions such as bank staff behavior, bank services comprehensiveness, bank services appropriateness with customers' needs, the quality of services provided by bank and bank physical quality. This axial category depends on field conditions like "customer's attitude" and "customer's expectations" and environmental conditions and external factors like "the behavior of other present customers in bank" and "the opinions of friends and family about bank" are also influential. In order to achieve the main consequence which is customer satisfaction and 
loyalty, the banks need to use strategies like "the system of receiving and dealing with customers' complaints" and "the system of managing communications of bank customers". Other studies also emphasized on the importance of many items mentioned in the model obtained from the present study (9-14).

Also all hypotheses approved in the quantitative part of this study and therefore:

There is a significant relationship between bank staff behavior and customer's perception facing with service. This result is consistent with a study which focuses on the role of staff's moral behavior with customers (15) also there is a significant relationship between banks services comprehensiveness, banks services appropriateness with customers' needs, the quality of services provided by bank, bank physical quality, customer's attitude, customer's expectations, the behavior of other present customer in bank branch and the opinions of friends and family about bank with customer's perception facing service. These results are also consistent with other studies in this field (16-19). On the other hand, customer's attitude and expectations and the behavior of other customers is undoubtedly related to the system of receiving and dealing with bank customers' complaints and the system of managing communications with bank customers. This result is consistent with other studies in this field $(20,21)$.

At last, according to the results it was revealed that there is a significant relationship between system of managing communications with bank customers and the system of receiving and dealing with bank customers' complaints and customer satisfaction and loyalty. This result is consistent with other existing studies in this field (22).

Therefore, research ultimate model (based on approved hypotheses) extracted as follows:

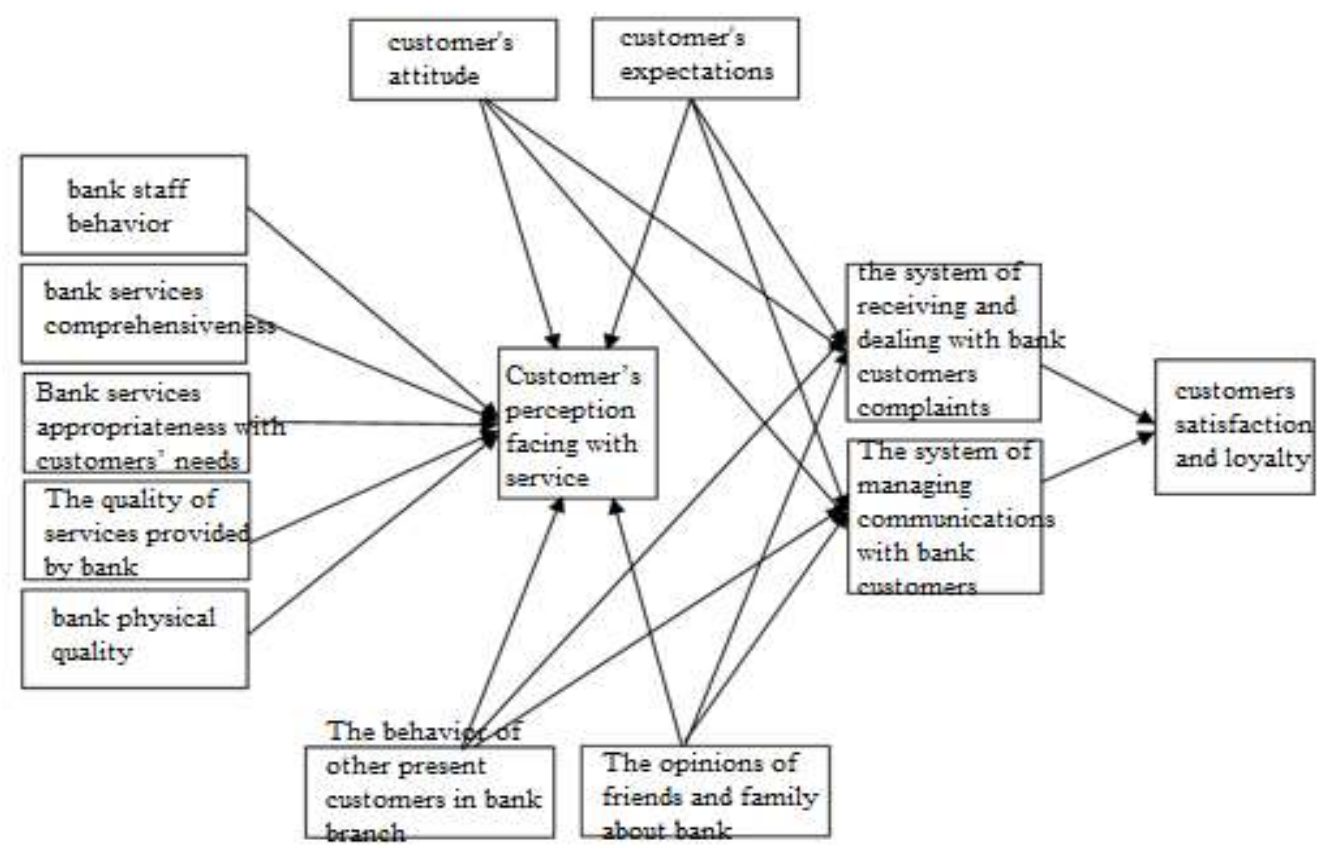

Figure 3: Research ultimate model

According to the results obtained from the research quantitative and qualitative phases and in line with reducing services failures and improving services quality in Iran's banking industry, the following recommendations are suggested:
- Bank staff uniforms be coordinated, ordered and beautiful.

- Bank staff behave with customers politely and tactfully. 
- Bank customers be patient in responding to customers.

- Banks provide customers with diverse services.

- Banks adapt themselves with customers' diverse needs in financial services field.

- Banks consider customers' future needs.

- Banks consider customers' hidden needs.

- Banks act perfectly customer-oriented in designing their services.

- Bank services provided accurately.

- Bank services provided with acceptable speed.

- Bank services on time.

- The process of providing services in bank be perfectly clear and obvious.

- Banks consider branches dispersion in different points of city.

- City location be considered considering easy access, car parking lot and...

- Bank branches be acceptable considering appearance quality, order and cleanliness.

- Bank branches enjoy suitable welfare facilities for customer waiting to receive services.

- Banks pay especial attention to branding.

- Banks pay especial attention to customers' expectations.

- Banks pay attention to the moment of receiving services by customers and mange it.

- Banks prevent arguing with customer and staff (and vice versa).

- Banks try to use the power of word-of-mouth marketing in online social networks to manage customers' mentality.

- Banks have an accurate system to receive customers' complaints.

- Banks deal with customers' complaints rapidly and immediately.

- Banks inform customers about dealing with their complaints step by step.

- Banks have accurate information about their customers' demands and needs.

- Banks be in touch with customer before, during and after providing service through different methods and instruments.
- Banks be in touch with their customers to transfer their comment on improving quality and service failure to bank.

\section{Conclusion}

Responsibility has turned into an obvious and acceptable matter as one of the indices of citizenship behavior among all social organizations and systems. Although, this concept (responsibility) is known as new concepts of the present era, it has made organizations and todays' managers pay attention to environmental needs and their services customers and consumers and focus on this purpose in their organizational missions and strategies in the best form. Undoubtedly, customer's satisfaction and loyalty depends on organization adherence to professional ethics and responsibility that the most important responsibility sign of an organization is organized activity to compensate for services failure and reviving it to increase customers' satisfaction and not considering this important matter threatens company survival in long term.

\section{Ethical Consideration}

In order to comply with the research ethic, the purpose of the research was first explained to the participants and they were assured that the findings are only for research work that has no other use and can be removed whenever the participants do not want to continue the interviews.

\section{Acknowledgement}

We owe it to ourselves to thank all the people who helped us in this research.

\section{References}

1. Estiri M, Hosseini F, Yazdani H (2011). Determinants of customer satisfaction in Islamic banking: evidence from Iran. International Journal of Islamic and Middle Eastern Finance and Management, 4 (4): 295-307.

2. Sandra M, Correia L, Hans R, Kaufmann SR (2014). Intentions to use and recommend to others: An empirical 
study of online banking practices in Portugal and Austria. Online Information Review, 38 (2): 186 - 208.

3. Mihelis G, Grigoroudis E, Siskos Y, Politis Y, Malandrakis Y (2001). Customer satisfaction measurement in the private bank sector. European Joumal of Operational Research, 130 (2): $347-360$.

4. Martínez E, Teresa M, José MP (2009). Brand extension feedback: The role of advertising. Journal of Business Research, 62: 305-313.

5. Lee Bruce CY (2012). The determinants of consumer attitude toward service innovation - the evidence of ETC system in Taiwan. Journal of Services Marketing, 26 (1): 9-19.

6. Grönroos C (2017). Relationship marketing readiness: theoretical background and measurement directions. Journal of Services Marketing, 31 (3): 218-225.

7. Zeithaml VA (1988). Consumer perceptions of price, quality and value: a means-end model and synthesis of evidence. Journal of Marketing, 52: 2-22.

8. Farooq MSH, Maimoona S, Alain F, Norizan J, Kartinah A (2018). Impact of service quality on customer satisfaction in Malaysia airlines: A PLS-SEM approach. Journal of Air Transport Management, 67: 169-180.

9. Hartfeil $F(1996)$. Bank one measures profit ability of customers, not just products. Journal of retail banking services, 18 (2).

10. Hu HH, Kandampully J, Juwaheer TD (2009). Relationships and impacts of service quality, perceived value, customer satisfaction, and image: an empirical study. The Service Industries Journal, 29(2): 111-125.

11. Zavareh FB, Ariff MS, Jusoh A, Zakuan N, Zaidi BA (2012). E-Service quality dimensions and their effects on ecustomer satisfaction in internet banking services. Procedia - Social \& Behavioral Sciences, 40: 441 - 445.

12. Hashim Z, Anam T, Uzma K, Aisha M (2015). Impact of service quality, corporate image and customer satisfaction towards customers' perceived value in the banking sector in Pakistan. International Journal of Bank Marketing, 33 (4): 442-456.

13. Adrian P, Pennie F (2017). Relationship marketing: looking backwards towards the future. Joumal of Senvices Marketing, 31 (1): 11-15.

14. Danaher P, Gallagher Rodger W (1997). Modeling customer satisfaction in telecom New Zealand. European Journal of Marketing, 31(2).

15. Ganguli Sh, Roy SK. (2011). Generic technology-based service quality dimensions in banking impact on customer satisfaction and loyalty. International Journal of Bank Marketing, 29 (2): 168-189.

16. Xuemei X, Yaoyang J, Xiaohua M, Chao L (2017). Corporate social responsibility, customer satisfaction, and financial performance: The moderating effect of the institutional environment in two transition economies. Journal of Cleaner Production, 150: 26-39.

17. Turban E, King DLJ, Chung HM, Warkentin M (2004). Electronic commere: a managerial perspective. Pearson Education, New Jersey/USA.

18. Michael HK, Chris C, Carolyn FM, Kathryn WE (2016). Consumer preferences for banking technologies by age groups. International Journal of Bank Marketing, 34 (4): 587602.

19. Lymperopoulos C, Chaniotakis IE, Soureli M (2006). The importance of service quality in bank selection for mortgage loans. Managing Service Quality, 16 (4): 365-379.

20. Cameran M, Moizer P, Pettinicchio A (2010). Customer satisfaction, corporate image, and service quality in professional services. The Senvice Industries Journal, 30(3): 421-435.

21. Tsu-Wei Y, Lu-Ming T (2016). The role of salespeople in developing life insurance customer loyalty. International Journal of Retail \& Distribution Management, 44 (1): 22-37.

22. Mihelis G, Grigoroudis E, Siskos Y, Politis Y, Malandrakis Y (2001). Customer satisfaction measurement in the private bank sector. European Journal of Operational Research, 130 (2): 347-360. 